\title{
Correlation Physical Activity, Energy Balance, and Metabolic Syndrome of Physical Fitness in Elderly Age Group
}

\author{
Setiawan, Hanna Goenawan, Ronny Lesmana, Vita M. Tarawan, Aziiz M. Rosdianto, Ambrosius Purba \\ Department of Anatomy, Physiology, and Cell Biology Faculty of Medicine \\ Universitas Padjadajaran Bandung, Indonesia
}

\begin{abstract}
Fitness becomes an important benchmark for public health in every age group. Activities with poor adverse fitness are at risk of injury. Good fitness is gained from a balance in everyday physical activity with conditions that are free of metabolic syndrome. This study investigated the relationship of physical activity, energy balance, and metabolic syndrome to the fitness of 166 professors of Universitas Padjadjaran who underwent a 1-month fitness checkup at BAPELKES Bandung in the period of 2017. Based on the regression analysis, the results showed a significant relationship between physical activity, energy balance, and metabolic syndrome on the physical fitness of the elderly group $(\mathrm{F}=25.9290>\mathrm{F}$ table $=2.427$ ) with normal data distribution (Kolmogorov-Smirnov test). The results also showed a moderate relationship $(\mathrm{R}=0.569$ and $\mathrm{R} 2=0.324)$. It also partially showed significant influence between physical activity and fitness $(\mathrm{t}=8.541>\mathrm{t}$ table $=1.975)$, significant influence between energy balance and physical fitness $(\mathrm{t}=2.248>\mathrm{t}$ table $=1.975)$, and no significant partial influence between metabolic syndrome and physical fitness of the elderly group $(\mathrm{t}=-0.029<\mathrm{t}$ table $=1.975)$. Hence, there is a relationship between physical activity, energy balance, metabolic syndrome and physical fitness of Professors in Universitas Padjadjaran.
\end{abstract}

Key words: Energy balance, metabolic syndrome, physical fitness

\section{Hubungan Aktivitas Fisik, Keseimbangan Energi, dan Sindrom Metabolik terhadap Kebugaran Fisik pada Kelompok Usia Lanjut}

\begin{abstract}
Abstrak
Kebugaran menjadi tolak ukur penting bagi kesehatan masyarakat pada setiap kelompok usia. Aktivitas dengan kebugaran usia lanjut yang kurang baik berisiko terjadi cedera. Kebugaran yang baik diperoleh dari keseimbangan dalam aktivitas fisik sehari-hari dengan kondisi bebas dari sindrom metabolik. Penelitian ini mempelajari hubungan aktivitas fisik, keseimbangan energi, dan sindrom metabolik dengan kebugaran 166 orang Guru Besar di Universitas Padjadjaran yang dilakukan pemeriksaan kebugaran selama 1 bulan di BAPELKES Bandung periode tahun 2017. Berdasar atas analisis regresi hasil penelitian menunjukkan hubungan yang signifikan antara aktivitas fisik, keseimbangan energi, dan sindrom metabolik dengan kebugaran fisik kelompok usia lanjut $(\mathrm{F}=25,9290>$ Ftable $=2,427)$ dengan distribusi data normal (tes Kolmogorov-Smirnov). Hasil juga menunjukkan hubungan yang moderat $\left(\mathrm{R}=0,569\right.$ dan $\left.\mathrm{R}^{2}=0,324\right)$. Secara parsial juga menunjukkan pengaruh yang signfikan aktivitas fisik dengan kebugaran $(t=8.541>t$ tabel=1.975), pengaruh signifikan keseimbangan energi dengan kebugaran fisik $(\mathrm{t}=2,248>\mathrm{t}$ tabel $=1,975)$, dan tidak ada pengaruh signifikan secara parsial terhadap sindrom metabolik dengan kebugaran fisik kelompok usia lanjut $(\mathrm{t}=-0,029<\mathrm{t}$ tabel=1,975). Berdasar atas hasil penelitian dapat disimpulkan hubungan = aktivitas fisik, keseimbangan energi, dan sindrom metabolik dengan kebugaran fisik guru besar Universitas Padjadjaran.
\end{abstract}

Kata kunci: Kebugaran, keseimbangan energi, sindrom metabolik

Correspondence: Prof. Dr. Ambrosius Purba, dr., MS., AIFO, Department of Anatomy, Physiology, and Cell Biology Faculty of MedicineUniversitas Padjadjaran,Jalan Raya BandungSumedang KM. 21, Jatinangor,Sumedang,E-mail:amrosdianto@gmail.com 


\section{Introduction}

Physical function, or physical ability, was defined as the degree to which a person can manage the physical tasks and fitness of daily living. Physical fitness represents a person's general physical health status. ${ }^{1,2}$ The level of physical fitness is associated with age-associated diseases such as hypertension, metabolic syndrome, diabetes, and cognitive impairment. . $^{3,4}$

Elderly has become an important group that increasingly requires special attention with respect to health and social issues. The health of the elderly proceeds on a continuum that begins with development symptoms associated with daily activity changes, the low endurance of fitness, biological changes, continues to disease onset, functional loss and disability, and ultimately, terminal status and death. ${ }^{5-8}$

Regular physical activity (PA) can improve physical fitness (PF) and health and help prevent diseases. ${ }^{9-11}$ Several studies have shown that physically active adults are healthier and have a higher PF than inactive adults throughout different nations and populations groups..$^{12} \mathrm{PA}$ is therefore promoted as part of a healthy lifestyle. ${ }^{12}$ The current understanding of the relationship between PA, PF, and health can be visualized using the model from Bouchard et al. The model illustrates that PA can influence fitness and health and that the relationships are also reciprocal. Additionally, other factors such as personal and social attributes age, sex, and socioeconomic status (SES) are known to influence PF, Health status, PA, and their relationships. ${ }^{12}$

Energy balance is the state in which energy expenditure (EE) equals metabolism energy intake (EI) so that the overall energy content of the body remains stable. ${ }^{12} \mathrm{~A}$ negative energy balance occurs when EE is greater than EI, and a positive energy balance occurs when EI is greater than EE. The extent to which exercise changes energy balance depends on the extent to which the increase in EE due to exercise balanced by a compensatory increase in EI. The intuitive common-sense view is that an increase in activity EE (AEE) follow by an equivalent increase in EI. ${ }^{13,16,17}$

The case of metabolic syndrome consists of a cluster of risk factors for cardiovascular disease that comprises abdominal obesity, impaired glucose tolerance, hypertension, and dyslipidemia. When thesefactors appear together the cardiovascular risk rises substantially. In Spain, the prevalence of metabolic syndrome is $42.1 \%$ in men and $32.3 \%$ in women, and it increases with age. ${ }^{14}$

A considerable body of epidemiological evidence indicates that the most prevalent diseases in developed societies, including metabolic syndrome, are closely linked to lifestyle factors, notably smoking, unhealthy dietary habits, physical inactivity, and stress. The increasing prevalence of metabolic syndrome and its negative impact on people and society has been mainly attributed to a decline in regular physical activity, an increase in sedentary behavior and changes in dietary habits. Given that these factors are all modifiable they reversed through interventions focusing on behavioral change. Changes in lifestyle can have a positive effect on prevalence cardiovascular risk factors and, therefore, on that of metabolic syndrome and cardiovascular diseases.

The aim of this study is to analyzed the correlation effect of Physical Activity, Energy Balance, and Metabolic Syndrome on Physical Fitness in Elderly Age Groups of Professors in Universitas Padjadjaran.

\section{Methods}

This research was conducted in Balai Pelayanan Kesehatan (BAPELKES) Universitas Padjadjaran, Bandung on 2016-2017. Total 166 men and women members of academic professor committee in Universitas Padjadjaran aged 5575 years were participated in this study.

Blood pressure were measured using sphygmomanometers (Riester, Riester Direct, CA, USA) by trained paramedics. Subjects standing body height were tested using a stadiometer (SECA, Hamburg, Germany). Body composition were measured using Tanita body composition analyzer type SC 331 (Tanita Corp. Inc., Arlington Height, USA). Food intake were assessed using 24 hours dietary recalls for two consecutive days by trained nutritionist. Global Physical Activity Questionnaire (WHO) were used to measure daily physical activity. The cardiorespiratory endurance were measured using 6-min run test.

Metabolic syndrome were assessed with ATP III criteria including fasting blood glucose, triglyceride level and obesity. Blood sample were taken between 7 and 8 a.m. after overnight fast. The serum was taken and subjected for fasting blood glucose level measurement and triglyceride level.

Sampling was done using purposive sampling method. Data were Statistically analyzed using computer software SPSS 16.0 for Windows. 
Normal distribution of data was examined with Kolmogorov-Smirnov test.Differences between groups were assessed using independent $t$ test and correlation analysis were using Pearson correlation coefficient.

This study was approved by Ethical Committee of Faculty of Medicine, Universitas Padjadjaran, Bandung, Indonesia, Ethical number 96/UN6.C1.3.2/KEPK/PN/2016. All procedure were informed to the subjects before physical examination and testing, Written consent was signed by all participants.

\section{Results}

Table 1 describes the characteristics of the participants. Approximately $54.8 \%$ of the participants were having moderate daily activity, $44 \%$ having low activity and $1.2 \%$ participants having good activity. Energy balance were shown in Table 1. Positive energy balance was found in most of the participants (84.9\%), while negative energy balance was found in $1.2 \%$ participants. The metabolic syndrome variable shows that $26.5 \%$ participant fulfill metabolic syndrome criterias whereas the other (73.5) have no metabolic syndrome. The physical fitness variable shows that the sample was mostly in low physical fitness $(46.4 \%)$, medium physical fitness $(24.7 \%)$, and a small percentage were in mild physical fitness and sedentary $(14.45 \%)$.

The results show that data was normally distributed after performing KolmogorovSmirnov test $(p=0.000)$ (Table 2). From the analysis results obtained by the multiple

Table 1 Characteristics of the Participants

\begin{tabular}{llc}
\hline \multicolumn{1}{c}{ Variable } & \multicolumn{1}{c}{ Category } & $\begin{array}{c}\text { \% } \\
\text { (n=166) }\end{array}$ \\
\hline Physical & Low & 44 \\
activity (PA) & Moderate & 54.8 \\
& Good & 1.2 \\
Energy & Negative & 1.2 \\
Balance & StablePositive & 13.9 \\
& & 84.9 \\
Metabolic & Include & 26.5 \\
Syndrome & Not include & 73.5 \\
& Mild & 14.45 \\
Physical & Low & 46.4 \\
Fitness & Medium & 24.7 \\
& Sedentary & 14.5 \\
\hline
\end{tabular}

Table 2 Variable Distributions

\begin{tabular}{lcc}
\hline \multicolumn{1}{c}{ Parameter } & Mean \pm SD & p-value* \\
\hline Physical activity & $1.33 \pm 0.495$ & 0.000 \\
Energy balance & $2.83 \pm 0.407$ & 0.000 \\
Metabolic syndrome & $0.27 \pm 0.443$ & 0.000 \\
Physical fitness & $1.81 \pm 1.025$ & 0.000 \\
\hline
\end{tabular}

*) p-value $<0.05$

regression equation $\mathrm{Y}=-0.739+1.144 \mathrm{X}_{1}+$ $0.372 \mathrm{X}_{2}-0.67 \mathrm{X}_{3}$. Multiple regression analysis data showed intermediate correlation interpretation based on correlation coefficient test $(\mathrm{R}=0.569)$. Multiple regression analysis data also showed that $32,4 \%$ contribution of dependent variable (Physical Fitness) and independent variable affect (physical activity, energy balance, and metabolic syndrome) based on result of a determination analysis $\left(\mathrm{R}^{2}=0.324\right)$.

The result of regression analysis after regression coefficient test showed a significant effect on physical activity, energy balance, and metabolic syndrome on physical fitness in elderly group $(\mathrm{F}=25.920>\mathrm{F}$ table $=2.4275)$. In this study, it can be concluded that physical activity, energy balance, and metabolic syndrome have together affected the physical fitness of the elderly group. Multiple regression analysis on partial regression coefficient test shows that is significant effect between physical activity and physical fitness of the elderly group $(\mathrm{t}=8.541>\mathrm{t}$ table $=1.975)$. The energy balance variable partially is significant effect between the balance of energy with physical fitness of the elderly group $(\mathrm{t}=2.248>\mathrm{t}$ table $=1.975)$. In metabolic syndrome variable showed partially no significant effect on metabolic syndrome on the physical fitness of the elderly group ( $t=-$ $0.029 \mathrm{t}$ table=1.975).

\section{Discussion}

The physical fitness overviews of Professors in Universitas Padjadjaran were mostly low. This was based on the result of the physical fitness assessment that was dominated by low category $(46,4 \%)$ and mild and sedentary category $(14,45 \%)$. Many professors did a moderate physical activity $(54,8 \%)$ and less with good physical activity $(1,2 \%)$. Majority of Professors with positive energy balance $(84,9 \%)$, whereas stable and negative energy balance were around $13,9 \%$. 
The regular physical activity (PA) can improve physical fitness (PF) and health and help prevent disease. ${ }^{15,16}$ Physically active adults have higher PF compared with sedentary adults based on studies throughout nations ${ }^{17,18}$. Incresing daily physical activity is effectively promoted as characteristics of a healthy lifestyle. ${ }^{19}$ Bouchard et al found that PA has reprocical influence with PA and health condition. ${ }^{20}$ In the other hand, personal and social attributes age, sex, and socioeconomic status (SES) have correlation with PF, health status and PA.. Further studies in needed to analyze the correlation among sex and education levels with PF, health status and PA.

Mostly Professors have positive energy balance $(84,9 \%)$ and less with stable energy balance $(13,9 \%)$. Understanding how the energy balance is altered by exercise may improve the care of two populations: those who want to lose fat and body mass, thus seeking a negative energy balance (overweight/obese population), and those who need to maintain an equilibrium between energy intake and expenditure (moderate to high-level athletes and soldiers). Concerning the first context, the rising worldwide incidence of obesity has become a major public health issue.$^{20}$ The main factors contributes to positive energy balance are sedentary lifestyle and high calory intake. Lifestyle modification is needed to decrease risk factor metabolic syndrome among professors. The effect of healthy diets on preventing weight (re)gain or reducing body mass in overweight/ obese individuals has been extensively studied and their benefits and main limits (weight regain after drastic diets undertaken to lose body mass) are well-known.. More research are needed to understand the physical activity among Professors in Universitas Padjadjaran.

In this study, 26.5\% professors has metabolic syndrome. Based on this finding, Indonesian academic population appears to have relatively high percentage of metabolic syndrome compared with other Asian countries. As comparison, metabolic syndrome rates in Phillipines and China are less than $20 \%{ }^{13}$. Therefore, strategic health policy and promotion are needed to decrease the prevalence of metabolic syndrome among professors in Universitas Padjadjaran.

Based on the results and analysis concluded that physical activity, the balance of energy, and metabolic syndrome affects the physical fitness of the elderly group professors in Universitas Padjadjaran.

\section{Acknowledgement}

This research were supported from Academic Leadership Grants 2017 Universitas Padjadjaran (AP). All authors thanks to Titing Nurhayati, Nova Sylviana, Yuni S. Pratiwi, Juliati, Reni Farenia, Fathul Huda for their significant contributions.

\section{References}

1. Soriano-Maldonado A, Ruiz JR, Aparicio VA, Estévez-López F, Segura-Jiménez V, ÁlvarezGallardo IC, et al. Association of physical fitness with pain in women with fibromyalgia. Arthritis Care Res. 2015;67(11):1561-570.

2. Hye-Sang P, Kyu-Tae L, Tae-Woon K. Role of physical activity in mortality prediction in elderly hospice patients. J Exercise Rehabilitat. 2017;13(2):250-4.

3. Bootsma-van derWiel A, Gussekloo J, De Craen AJ, Van-Exel E, Bloem BR, Westendorp RG. Common chronic diseases and general impairments as determinants of walking disability in the oldest-old population. J Am Geriatr Soc. 2002;50(8):1405-10.

4. Juraschek SP, Blaha MJ, Whelton SP, Blumenthal R, Jones SR, Keteyian SJ, et al. Physical fitness and hypertension in a population at risk for cardiovascular disease. J Am Heart Assoc. 2014;3(6):124-8.

5. Cooper R, Kuh D, Cooper C, Gale CR, Lawlor DA, Matthews F, Hardy R. Objectively measured physical capability levels and mortality: systematic review and metaanalysis. BMJ. 2010;341:1-12.

6. Cooper R, Kuh D, Cooper C, Gale CR, Lawlor DA, Matthews F, et al. Objective measures of physical capability and subsequent health. Age Ageing. 2011;40(1):14-23.

7. Rizzuto D, Fratiglioni L. Lifestyle factors related to mortality and survival. Gerontology. 2014;60:327-35.

8. van der Velde JHPM, Savelberg HHCM, van der Berg JD, Sep SJS, van der Kallen CJH, Dagnelie PC4, et al. Sedentary behavior is only marginally associated with physical function in adults aged 40-75 years. Front Physiol. 2017;8:239-42.

9. Blair SN, Church TS. The fitness, obesity, and health equation: is physical activity the common denominator?. JAMA. 2004; 292(10):1232-4.

10. Piepoli MF, Hoes AW, Agewall S, Albus C, Brotons C, Catapano AL, et al. European 
guidelines on cardiovascular disease prevention in clinical practice: the sixth joint task force of the european society of cardiology and other societies on cardiovascular disease prevention in clinical practice (constituted by representatives of 10 societies and by invited experts) developed with the special contribution of the EACPR. Eur Heart J. 2016;37(29):2315-81.

11. chmidt SCE, Tittlbach S, Bös K, Woll A. Different types of physical activity and fitness and health in adults: an 18-year longitudinal study. Biomed Res Int. 2017;2017:1-10.

12. Kuh D, Bassey EJ, Butterworth S, Hardy R, Wadsworth ME. Grip strength, postural control, and functional leg power in a representative cohort of british men and women: associations with physical activity, health status, and socioeconomic conditions. J Gerontol A BiolSci Med Sci. 2005;60(2): 224-31.

13. WHO. Global recommendations on physical activity for health. World Health Organization [online] 2010 [Cited 2017 December 20]. Available from: http://apps.who.int/stre am/10665/44399/1/9789241599979_eng. pdf.

14. Katarina M, Anne R, Stefanie Z, Céline T, Jan L, Davide $\mathrm{M}$, et al. Alterations in energy balance from an exercise intervention with ad libitum food intake. J Nutr Sci. 2016;5(7):1-10.

15. Marcuello C, Calle-Pascual A, Fuentes
M, Runkle I, Rubio M, Montañez C, et al. Prevalence of the metabolic syndrome in Spain using regional cutoff points for waist circumference. Acta Diabetol. 2013;50(4):615-23.

16. Dionne IJ, Ades PA, Poehlman ET. Impact of cardiovascular fitness and physical activity level on health outcomes in older persons. Mech Ageing Dev. 2003;124(3):259-67.

17. Kuh D, Bassey EJ, Butterworth S, Hardy R, Wadsworth ME. Grip strength, postural control, and functional leg power in a representative cohort of British men and women: associations with physical activity, health status, and socioeconomic conditions. J Gerontol BiolSci Med Sci. 2005;60(2):22431.

18. Yatsuya H, Li Y, Hilawe EH, Ota A, Wang C, Chiang $\mathrm{C}$, et al. Global trend in overweight and obesity and its association with cardiovascular disease incidence. Circ J. 2014;78(12):2807-18.

19. Gurnani M, Birken C, Hamilton J. Childhood obesity: causes, consequences, and management. Pediatr Clin North Am. 2005; 62(4):821-40.

20. Ramírez-Vélez R, Anzola A, Martinez-Torres J, Vivas A, Tordecilla-Sanders A, PrietoBenavides D, et al. Metabolic syndrome and associated factors in a population-based sample of schoolchildren in colombia. Metab Syndr Relat Disord. 2016;14(9):455-62. 